\title{
Variation in susceptibility of rapeseed cultivars to the peach potato aphid
}

\author{
Bożena Kordan ${ }^{1} \cdot$ Anna Wróblewska-Kurdyk ${ }^{2} \cdot \operatorname{Jan}$ Bocianowski $^{3}$ (D) Katarzyna Stec ${ }^{2} \cdot \mathrm{Krzysztof} \mathrm{Jankowski}^{4}$. \\ Beata Gabryś ${ }^{2}$ ()
}

Received: 17 October 2019 / Revised: 2 August 2020 / Accepted: 6 August 2020 / Published online: 13 August 2020

(c) The Author(s) 2020

\begin{abstract}
Considering the need for reduction in insecticide use, we studied the potential for antibiosis and the potential for antixenosis in seven highly yielding winter Brassica napus L. cultivars against Myzus persicae (Sulz.). We found evidence for antixenosis, i.e., disruption in probing in non-phloem tissues and a failure in reaching sieve elements in cultivar 'Alister'. We found evidence for antibiosis, i.e., reduced ability of the plant to serve as a host, in cultivar 'Florida'. On 'Alister' and 'Florida', net reproduction and reproductive period duration of M. persicae were the lowest of all studied cultivars. 'Adriana', 'Andromeda', 'Gladius', and 'Kolumb' are intermediately susceptible to $M$. persicae infestation with medium values of net reproduction and reproduction period duration, and slight disturbances in aphid probing and feeding. 'Artoga' is highly susceptible. On 'Artoga', reproduction period was the longest, daily fecundity and net reproduction of M. persicae were highest, and probing and feeding behaviors were unaltered. Glucoallysin, glucobrassicanapin, gluconapin, gluconapoliferin, progoitrin, glucobrassicin, and 4-OH-glucobrassicin occurred in the leaves of all rapeseed cultivars in similar quantities and proportions and did not affect aphid performance and phloem sap ingestion by M. persicae.
\end{abstract}

Keywords Plant resistance $\cdot$ Glucosinolates $\cdot$ Probing behavior $\cdot$ Electrical penetration graph

\section{Key message}

Communicated by Han Peng.

Electronic supplementary material The online version of this article (https://doi.org/10.1007/s10340-020-01270-2) contains supplementary material, which is available to authorized users.

Beata Gabryś

b.gabrys@wnb.uz.zgora.pl

Bożena Kordan

bozena.kordan@uwm.edu.pl

Anna Wróblewska-Kurdyk

a.wroblewska@wnb.uz.zgora.pl

Jan Bocianowski

jan.bocianowski@up.poznan.pl

Katarzyna Stec

katarzyna.rozycka1985@interia.pl

Krzysztof Jankowski

krzysztof.jankowski@uwm.edu.pl
- Probing behavior and development of Myzus persicae were studied to select the least susceptible Brassica napus cultivars.

- Low susceptibility of cultivar 'Alister' depends on antixenosis, and low susceptibility of 'Florida' is caused by antibiosis.

1 Department of Entomology, Phytopathology and Molecular Diagnostics, University of Warmia and Mazury in Olsztyn, Prawocheńskiego 17, 10-719 Olsztyn, Poland

2 Department of Botany and Ecology, University of Zielona Góra, Szafrana 1, 65-516 Zielona Góra, Poland

3 Department of Mathematical and Statistical Methods, Poznań University of Life Sciences, Wojska Polskiego 28, 60-637 Poznań, Poland

4 Department of Agrotechnology, Agricultural Production Management and Agribusiness, University of Warmia and Mazury in Olsztyn, Oczapowskiego 8, 10-719 Olsztyn, Poland 
- Cultivars 'Adriana', 'Andromeda', 'Gladius', and 'Kolumb' are intermediately susceptible, and 'Artoga' is highly susceptible to $M$. persicae infestation.

- Glucosinolates in leaves of rapeseed cultivars studied do not affect $M$. persicae probing and feeding behaviors.

\section{Introduction}

Oilseed rape Brassica napus L. (Brassicaceae) is one of the most cultivated and profitable crops worldwide due to its rising significance in food and feed production, industry, energy generation, and environmental protection (Ackman 1990; Jang et al. 2011; Nosenko et al. 2014; Jankowski et al. 2015a, b; FAOSTAT 2018). Within the guild of herbivores that reduce rapeseed yield, the polyphagous and cosmopolitan peach potato aphid Myzus persicae (Sulz.) (Hemiptera: Aphididae) has a particular status. In addition to plant nutrient removal by feeding on phloem sap, $M$. persicae transmits more than 100 plant viruses, including the persistent Turnip yellows virus (TuYV) (Stevens et al. 2008; Ekbom 2010; Nooh 2012; Blackman and Eastop 2017). An increased risk of virus infection in the growing acreage of oilseed rape may be expected, since $M$. persicae annual numbers are positively correlated with the acreage of agricultural crops, especially oilseed rape (Cocu et al. 2005). The population of $M$. persicae is usually dispersed over the crop area (Blackman and Eastop 2017). The infestation by M. persicae may also increase the susceptibility of rapeseed to fungal pathogens (Drizou et al. 2018). The timing of M. persicae spring migration is determined by winter temperature (Bale et al. 1988). Warmer conditions due to climate change will encourage the survival and multiplication of $M$. persicae throughout the winter (Cocu et al. 2005), which may lead to extensive spread of TuYV in the following spring (Stevens et al. 2008). If aphid attacks become more frequent, possibly in association with climate change, virus problems in oilseed rape may become more serious (Ekbom 2010). Exceptionally high infestations by $M$. persicae and TuYV infections occurred in oilseed rape in Poland and other European countries in the autumn seasons of 2016, 2017 and 2018 (Limagrain Central Europe 2018).

The cessation of neonicotinoid seed treatments in oilseed rape, which became effective in 2013, caused serious crop losses in 2014, 2015 and 2016 owing to insect pests, including aphids (Dewar 2017). Until present, the major goals for oilseed rape breeding were tolerance to late planting and winter hardiness, plant height and lodging resistance, resistance to blackleg disease, very low contents of erucic acid and glucosinolates, high oil content and marketable seed yield (Friedt and Snowdon 2009). Considering the trends for reduction of insecticide use, the exceptional ability of M. persicae to overcome the effect of insecticide application
(Bass et al. 2014) and the growing risk of aphid population increase due to climate change, the attention of plant breeders should be turned toward plant resistance to this aphid species, especially antixenosis and antibiosis mechanisms. Antixenosis is based on the modification of herbivore behavior by plant mechanisms, which results in the inability of a plant to serve as a host. Antixenosis against aphids is manifested in the disturbance in aphid probing and feeding behaviors leading to low or non-acceptance of the plant. Antibiosis occurs when the resistant plant affects the biology of an herbivore trying to use that plant as a host, without changing herbivore behavior (Smith 2005; Le Roux et al. 2008; Smith and Chuang 2014; van Emden 2017). In Brassicaceae, glucosinolates are the major defensive constitutive and inducible metabolites responsible for antixenosis and/or antibiosis-based resistance to most of the insect herbivores, including M. persicae (Cole 1997a; Brader et al. 2006; Kim and Jander 2007; Ahuja et al. 2010). Breeding efforts gave rise to oilseed rape cultivars whose glucosinolate content was reduced 15-16-fold, which maximized the utilization of protein from the fat-free seed residues but increased susceptibility to the infestation of a number of pests (Przybylski 2011). A limited search for oilseed rape genotypes resistant to $M$. persicae has been conducted, but the published reports are scarce and contain only fragmentary data on aphid population development and response to glucosinolates (Weber et al. 1986; Fathi et al. 2010; Sarwar and Sattar 2013). Aphids may contact glucosinolates that are stored in mesophyll cells (Gabryś and Tjallingii 2000) during short (5-10 s) probes into these cells when small samples of sap are taken for gustatory purposes (Powell, 1991; Martin et al. 1997) and during the ingestion of the phloem sap (Chen et al. 2001). The electronic recording of aphid probing behavior known as Electrical Penetration Graph (EPG) technique is an invaluable tool in revealing the tissular localization of antixenosis mechanisms in the host plant and the influence of these mechanisms on particular phases of aphid probing (Gabryś et al. 2015; Paprocka et al. 2018). There exists only one report on $M$. persicae probing behavior on rapeseed (Cole 1997b). The susceptibility of rapeseed cultivars to $M$. persicae has never been evaluated basing on such studies.

Considering the recurring autumn outbreaks of M. persicae in winter oilseed rape, the risk of TuYV infection and the lack of literature data on potential resistance mechanisms against $M$. persicae in rapeseed, the aim of the present study was to evaluate the susceptibility of several popular and highly yielding winter $B$. napus cultivars to $M$. persicae at vegetative growth stage (2-3 leaves unfolded) that represents the early autumn phase of $B$. napus winter cultivars development. The probing behavior of $M$. persicae using the EPG technique was studied to reveal the antixenosis potential in these cultivars. The qualitative and 
quantitative spectrum of glucosinolates in plant leaves was also determined to investigate the possible role of these allelochemicals as resistance mechanisms that may impede $M$. persicae probing and feeding on B. napus. Additionally, the development and life parameters of $M$. persicae were studied to examine the antibiosis potential in $B$. napus cultivars.

\section{Material and methods}

\section{Plants}

Seven cultivars of winter oilseed rape were studied:

1 'Adriana' - open-pollinated cultivar (Limagrain Europe S.A.; registered in Poland in 2008), seed glucosinolates $8.8-11.9 \mu \mathrm{M} / \mathrm{g}$,

2 'SY Alister' - hybrid cultivar (Syngenta Crop Protection AG; registered in Poland in 2014), seed glucosinolates $7.8-12.2 \mu \mathrm{M} / \mathrm{g}$

3 'Andromeda' - hybrid cultivar (Limagrain Europe S.A.; registered in Poland in 2012), seed glucosinolates 8.3$12.0 \mu \mathrm{M} / \mathrm{g}$,

4 'Artoga'-hybrid cultivar (Limagrain Europe S.A.; registered in Poland in 2010), seed glucosinolates 9.5$12.6 \mu \mathrm{M} / \mathrm{g}$,

5 'SY Florida' - hybrid cultivar (Syngenta Crop Protection AG; registered in Poland in 2015), seed glucosinolates $10.2-13.6 \mu \mathrm{M} / \mathrm{g}$,

6 'Gladius' - hybrid cultivar (Syngenta Crop Protection AG; registered in Poland in 2010), seed glucosinolates $10.4-12.5 \mu \mathrm{M} / \mathrm{g}$,

7 'SY Kolumb' - hybrid cultivar (Syngenta Crop Protection AG; registered in Poland in 2010), seed glucosinolates $7.4-11.2 \mu \mathrm{M} / \mathrm{g}$.

These cultivars were selected basing on their yielding and economic efficiency. The yielding of the studied cultivars was 10-20\% higher than that of reference cultivar in crop cultivar trials conducted by The Research Centre for Cultivar Testing (COBORU) in Słupia Wielka near Poznań (Bundessortenamt 2014; Porejestrowe Doświadczalnictwo Odmianowe 2019; Wyniki Porejestrowych Doświadczeń Odmianowych 2015, 2018). The seeds were provided by the University of Warmia and Mazury Experimental Station Bałcyny, Sp. Z o. o. Plants were grown in the chamber Sanyo MLR-351H (Sanyo Electronics Co. Ltd.). Parameters were designed to mimic typical climatic field conditions during planting season of winter oilseed rape: L14:10D photoperiod, 70\% r.h., and temperature, as presented in Figure S1.

\section{Aphids}

The peach potato aphid Myzus persicae (Sulz.), kept as a multiclonal colony on Chinese cabbage Brassica rapa subsp. pekinensis (Lour.) Hanelt., was reared in the laboratory at $20^{\circ} \mathrm{C}, 65 \%$ r.h., and L16:D8 photoperiod. The laboratory culture of M. persicae has been maintained at the Department of Botany and Ecology, University of Zielona Góra, since 2008. To maintain the colony vitality, apterous aphids were transferred to non-infested plants every other week. Transfer of aphids to new plants consisted of excising an aphid-infested leaf and placing it atop of new plants to allow independent aphid movement to fresh plant leaves.

\section{Aphid performance}

One adult apterous female $M$. persicae was placed on a plant at $\mathrm{BBCH}$ growth stages 12-13 (two to three leaves unfolded, according to the universal plant development decimal code provided by Biologische Bundesanstalt, Bundessortenamt and CHemical industry) (Meier 2018) for $24 \mathrm{~h}$. After $24 \mathrm{~h}$, the female and all progeny except one nymph were removed. Each plant was isolated within a plastic cylinder with a fine mesh on top. The development of the nymph until maturity and the number of the newly born nymphs were monitored daily, and all newborn nymphs were removed. The experiment was terminated with the death of the mother aphid. The following parameters were evaluated: duration of pre-reproductive period (from birth to the first nymph laid), daily fecundity (number of nymphs laid each day), total fecundity (number of nymphs laid by one female), mother aphid longevity, net reproductive rate $(R 0$; females/ female $^{-1}$ generation $\left.^{-1}\right)$, intrinsic rate of natural increase $\left(r_{m}=[0.74(\operatorname{lnMd})] / D\right.$, where 0.74 is the constant for aphids and mites, Md is the number of nymphs produced in the first $D$ days of reproduction after the adult moult, and $D$ is the development time of the aphid (i.e., from birth to the final moult but before the onset of reproduction), mean generation time $\left(T=\ln (R 0) / r_{m}\right)$ (Wyatt and White 1977; Awmack and Leather 2002; Leather et al. 2017). The experiment was replicated 15 times for each oilseed rape cultivar.

\section{Aphid probing behavior}

Myzus persicae probing and feeding were monitored using the technique of electronic recording of aphid probing in plant tissues, known as Electrical Penetration Graph (EPG) (Tjallingii 1995). Aphid and plant are made parts of an electric circuit, which is completed when the aphid inserts its stylets into the plant. Weak voltage is supplied in the circuit, and all changing electric properties are recorded as EPG waveforms that can be correlated with aphid activities and stylet position in plant tissues (Martin et al. 1997; 
Pettersson et al. 2017). In the present study, aphids were attached to a golden wire electrode with conductive silver paint and starved for $1 \mathrm{~h}$ prior to the experiment. Probing behavior of $M$. persicae on rapeseed cultivars was monitored for $8 \mathrm{~h}$ continuously with 4 - and 8-channel DC EPG recording equipment (www.epgsystems.eu). Signals were saved on the computer and analyzed using the PROBE 3.1 software provided by W. F. Tjallingii (www. epgsystems.eu). The following aphid behaviors were distinguished: no penetration (waveform 'np' - aphid stylets outside the plant), pathway phase-penetration of nonphloem tissues (waveforms ' $A, B$, and $C$ '), derailed stylet movements (waveform ' $F$ '), salivation into sieve elements (waveform ' $E 1$ '), ingestion of phloem sap (waveform ' $E 2$ '), and ingestion of xylem sap (waveform ' $G$ '). The parameters derived from EPGs were analyzed according to their frequency and duration in configuration related to activities in peripheral and vascular tissues (van Helden and Tjallingii 1993). The $E 1 / E 2$ transition patterns were included in $E 2$. ' $G$ ' and ' $F$ ' occurred sporadically; therefore, these events were combined with pathway activities in all calculations and defined as non-phloem activities. The waveform patterns that were not terminated before the end of the experimental period $(8 \mathrm{~h})$ were included in the calculations. In sequential parameters, when time to waveforms related to phloem phase ( $E 1$ or $E 2$ ) was calculated, the time from the 1 st probe until the end of the recording was used if no phloem phase occurred. In non-sequential parameters, when a given waveform had not been recorded for an individual, the duration of that waveform was given the value of 0 .

Aphids for EPG experiments were 2-3 days old (2-3 days after the final moult) viviparous apterous females selected randomly from the stock culture. According to Ten Broeke et al. (2013), the use of aphids of random ages gives a clear view of the behavior of adult aphids within a population. The plants used in the bioassays were at $\mathrm{BBCH}$ growth stages 12-13 (two to three leaves unfolded) (Meier 2018). Each aphid was given access to a freshly prepared plant. Each plant-aphid set was considered as a replication and was tested only once. The number of replications (=EPG recordings) for each plant cultivar was 20 . Recordings that terminated due to aphid falling from the plant or where EPG signal was unclear were discarded from analysis. Only the replications that included complete 8 -h recording were kept for analysis, which were: 'Adriana', $n=13$; 'Alister', $n=12$; 'Andromeda', $n=12$; 'Artoga', $n=12$; 'Florida', $n=12$; 'Gladius', $n=15$; 'Kolumb', $n=10$. All experiments were carried out under the same conditions of temperature, relative humidity (r.h.) and photoperiod as those used for the rearing of plants and aphids. All bioassays started at 10:00-11:00 h MEST (Middle European Summer Time). Aphids show distinct diurnal feeding activity, with peak activity during day time, independently of host plants (Joschinski et al. 2016; Beer et al. 2017; Pettersson et al. 2017).

\section{Statistical analysis}

Firstly, the normality of the distributions of the observed traits was tested using Shapiro-Wilk's normality test. Life table parameters and EPG parameters describing aphid probing behavior were calculated manually, and the mean and standard errors were subsequently calculated using the analysis Excel worksheet created by the authors especially for this study. Data thus obtained were analyzed by Kruskal-Wallis test and post hoc multiple comparisons of mean ranks for all groups (Dunn's test). All statistical calculations were performed using StatSoft, Inc. (2014) STATISTICA (data analysis software system), version 12. Additionally, the relationships among all the traits were estimated on the basis of correlation coefficients. The results were also analyzed using multivariate methods. The graphic distributions of cultivars, described by means of the observed traits: life table parameters, EPG-recorded aphid probing parameters and glucosinolate content, were obtained by means of the principal components analysis (PCA). These analyses were done in GenStat 18.

\section{Glucosinolate analysis}

The plant material was obtained from winter oilseed rape plants at BBCH growth stages 12-13, which corresponded with plant stage used for experiments on aphid development and probing behavior. Plant samples were stored under $-80^{\circ} \mathrm{C}$ for $24 \mathrm{~h}$ and lyophilized. Glucosinolates were isolated by the enzymatic desulfation procedure according to the Commission Regulation (EC) No 1864/90 (Commission of the European Communities 1990). In total, $200 \mathrm{mg}$ of freeze-dried material was transferred to test tubes and heated at $75{ }^{\circ} \mathrm{C}$ in a hot water bath for $1 \mathrm{~min}$. Next, glucosinolates were extracted three times with $2 \mathrm{ml}$ of boiling methanol (70\%), stirring occasionally with the UltraTurrax IKA T-25 homogenizer (Jankel \& Kunkel, Germany). The supernatants were centrifuged, combined and filled up to $10 \mathrm{ml}$. Glucotropaeolin was used as an internal standard. Desulfoglucosinolates were analyzed by HPLC according to the method described by Ciska et al. (2008). The separation was performed in an HPLC system with an autosampler (LC-20) and the SPD-M20A DAD detector (Shimadzu, Japan) using the LiChrospher ${ }^{\circledR} 100 \mathrm{RP}-18(5 \mu \mathrm{m}, 250 \times 4 \mathrm{~mm})$ column (Merck, Darmstadt, Germany) with a flow rate of $1.2 \mathrm{~mL} /$ min. Desulfo-glucosinolates were separated in a gradient of water and $20 \%$ acetonitrile as previously described (Ciska et al. 2008). 


\section{Results}

\section{Aphid performance}

Lifetime duration of $M$. persicae females varied, depending on the winter oilseed rape cultivar and ranged from $50.7 \pm 6.4$ days on B. napus 'Artoga' to $62.3 \pm 11.3$ days on 'Alister' (Table 1). The highest survival of aphids occurred on 'Alister' and the lowest on 'Andromeda', where 50\% of aphids survived 59 and 51 days, respectively (Fig. 1). The mean duration of pre-reproductive period of M. persicae did not differ significantly among aphids on oilseed rape cultivars studied and was approximately 14-15 days, which was roughly $25-29 \%$ of aphid lifetime (Table 1, Figs. 1, S2). The duration of reproductive period was the longest on 'Adriana' ( $35.1 \pm 4.7$ days) and occupied $62.7 \%$ of the aphid lifetime and the shortest on 'Florida' ( $21.8 \pm 4.8$ days), $41.4 \%$. The post-reproductive period was the shortest on 'Artoga' ( $4.6 \pm 2.5$ days $)$ and the longest on 'Alister' ( $21.1 \pm 10.3$ days), which accounted for $9.1 \%$ and $34.2 \%$ of aphid lifetime, respectively (Table 1, Figs. 1,

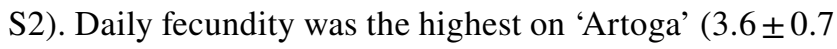
nymphs per day) and the lowest on 'Alister' $(1.9 \pm 0.6$ nymphs) (Table 1). The dynamics of reproduction also varied among aphids on different oilseed rape cultivars. On 'Adriana', 'Andromeda', 'Artoga' and 'Gladius', $M$. persicae consistently gave birth to 3-4 nymphs per day on average during the whole reproduction period, while on 'Alister', 'Florida' and 'Kolumb', the majority of nymphs were born during the first two weeks of the reproductive phase (Fig. 1). The net reproduction was the highest on
'Artoga' $(112.0 \pm 26.8$ nymphs per female $)$ and the lowest on 'Alister' and 'Florida' $(47.9 \pm 16.2$ and $56.7 \pm 17.8$, respectively). The mean time of generation development was the shortest on 'Florida' and the longest on 'Adriana' $(25.2 \pm 2.8$ and $31.2 \pm 3.8$ days, respectively). The intrinsic rate of natural increase was similar in all aphids in all oilseed rape cultivars studied (0.18-0.21) (Table 1).

\section{Aphid probing behavior}

Non-probing and pathway activities predominated during the initial 1-2 $\mathrm{h}$ of the experiment in all aphid individuals on all plants (Fig. 2). During the following hours, the proportion of non-probing phase activity decreased, while the proportion of non-phloem and phloem probing phases in aphid activities increased on 'Artoga', 'Florida' and 'Gladius'. At the end of the 8-h experiment, phloem phase was the main aphid activity on these cultivars, ranging from 53\% on 'Artoga' to $78 \%$ time on 'Florida'. The proportion of phloem phase remained relatively low on 'Adriana', 'Andromeda', and 'Kolumb' and scarce on 'Alister' during the whole experimental time (Fig. 2).

Total probing time was the longest on 'Andromeda' (89\% of experimental time) and the shortest on 'Alister' (34\%) (Table 2, Fig. 2). On 'Adriana', 'Artoga' and 'Kolumb', all aphids reached sieve elements and all showed sustained ingestion (Fig. 3). The proportion of phloem phase during probing was the highest on 'Florida' (60\% of experimental time), 'Artoga' (50\%) and 'Gladius' (50\%) and the lowest on 'Alister' (10\%) (Table 2, Fig. 2). The average probe was from 2.1 min on 'Alister' to 32 min long on 'Gladius'.

Table 1 Population parameters of Myzus persicae on oilseed rape Brassica napus cultivars studied

\begin{tabular}{|c|c|c|c|c|c|c|c|c|}
\hline & Adriana & Alister & Andromeda & Artoga & Florida & Gladius & Kolumb & $p$ \\
\hline Female longevity (days) & $56.0 \pm 7.8 \mathrm{ab}$ & $62.3 \pm 11.3 \mathrm{a}$ & $51.7 \pm 4.4 \mathrm{ab}$ & $50.7 \pm 6.4 b$ & $52.6 \pm 10.6 \mathrm{ab}$ & $56.4 \pm 5.8 \mathrm{ab}$ & $52.7 \pm 9.4 \mathrm{ab}$ & 0.0181 \\
\hline $\begin{array}{l}\text { Pre-reproduction period } \\
D \text { (days) }\end{array}$ & $14.0 \pm 2.9$ & $15.3 \pm 2.26$ & $14.2 \pm 1.0$ & $14.6 \pm 1.6$ & $14.6 \pm 1.8$ & $14.0 \pm 2.7$ & $14.1 \pm 2.2$ & 0.6444 \\
\hline $\begin{array}{l}\text { Reproduction period } \\
\text { (days) }\end{array}$ & $35.1 \pm 4.7 \mathrm{a}$ & $25.3 \pm 5.9 b$ & $32.6 \pm 6.5 a$ & $31.5 \pm 5.7 \mathrm{a}$ & $21.8 \pm 4.8 b$ & $33.3 \pm 8.3 \mathrm{a}$ & $29.6 \pm 7.1 \mathrm{ab}$ & 0.0000 \\
\hline $\begin{array}{l}\text { Post-reproduction } \\
\text { period (days) }\end{array}$ & $6.9 \pm 6.6 b c$ & $21.1 \pm 10.3 \mathrm{a}$ & $4.9 \pm 4.0 \mathrm{c}$ & $4.6 \pm 2.5 c$ & $16.2 \pm 9.2 \mathrm{ab}$ & $9.1 \pm 8.9 \mathrm{bc}$ & $8.9 \pm 7.3 \mathrm{abc}$ & 0.0000 \\
\hline Daily fecundity & $2.9 \pm 0.9 \mathrm{ab}$ & $1.9 \pm 0.6 \mathrm{c}$ & $2.9 \pm 0.5 \mathrm{ab}$ & $3.6 \pm 0.7 \mathrm{a}$ & $2.7 \pm 0.9 b c$ & $2.8 \pm 0.5 \mathrm{ab}$ & $2.4 \pm 0.5 b c$ & 0.0000 \\
\hline Net reproduction $(R 0)$ & $99.7 \pm 24.4 \mathrm{ab}$ & $47.9 \pm 16.2 \mathrm{c}$ & $92.5 \pm 18.4 \mathrm{ab}$ & $112.0 \pm 26.8 \mathrm{a}$ & $56.7 \pm 17.8 \mathrm{c}$ & $91.5 \pm 21.4 \mathrm{ab}$ & $70.3 \pm 15.2 b c$ & 0.0000 \\
\hline $\mathrm{Md} / R 0^{*}$ & $0.43 \pm 0.13 \mathrm{e}$ & $0.77 \pm 0.15 \mathrm{abc}$ & $0.53 \pm 0.18 \mathrm{de}$ & $0.50 \pm 0.09 \mathrm{e}$ & $0.75 \pm 0.20 \mathrm{bcd}$ & $0.55 \pm 0.19 \mathrm{de}$ & $0.68 \pm 0.18 \mathrm{cde}$ & 0.0000 \\
\hline $\begin{array}{l}\text { Mean time of generation } \\
\text { development }(T)\end{array}$ & $31.2 \pm 3.8 \mathrm{a}$ & $26.3 \pm 2.7 \mathrm{abc}$ & $28.7 \pm 3.9 \mathrm{abc}$ & $29.9 \pm 2.9 \mathrm{ab}$ & $25.2 \pm 2.8 \mathrm{c}$ & $29.1 \pm 5.6 \mathrm{abc}$ & $26.3 \pm 5.4 \mathrm{bc}$ & 0.0005 \\
\hline $\begin{array}{l}\text { Intrinsic rate of natural } \\
\text { increase }\left(r_{m}\right)\end{array}$ & $0.20 \pm 0.03$ & $0.18 \pm 0.03$ & $0.20 \pm 0.02$ & $0.20 \pm 0.03$ & $0.20 \pm 0.03$ & $0.19 \pm 0.03$ & $0.21 \pm 0.03$ & 0.0673 \\
\hline
\end{tabular}

Values are means $( \pm \mathrm{SD}), n=15$. Different letters in rows show significant differences at $p<0.05$ (Kruskal-Wallis test and post hoc multiple comparisons of mean ranks for all groups Dunn's test)

* Md: number of nymphs produced in the first $D$ days of reproduction after the adult moult 

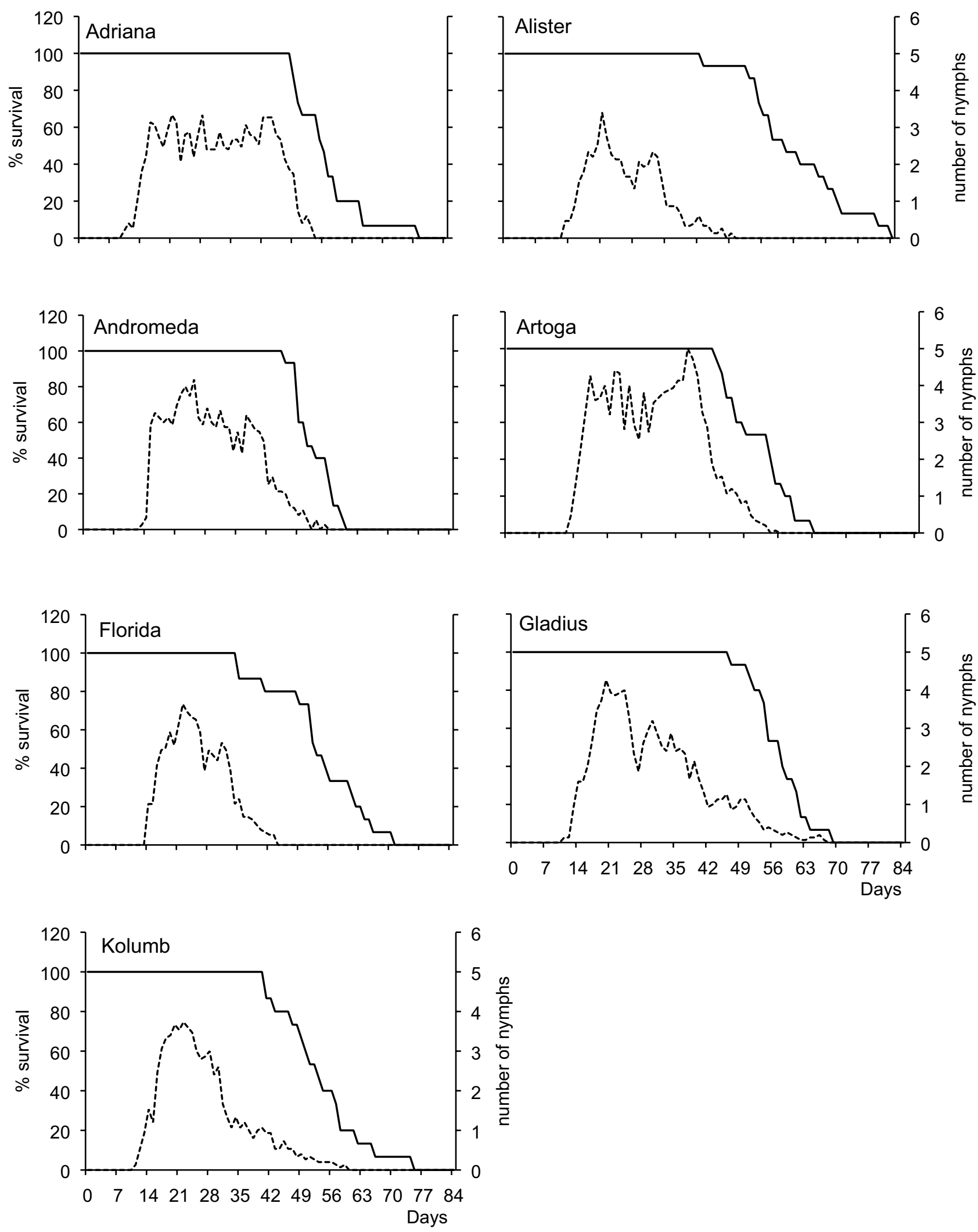

— $\%$ survival $\quad$-.--.-. fecundity/female

Fig. 1 Survival and fecundity of Myzus persicae on Brassica napus cultivars studied 

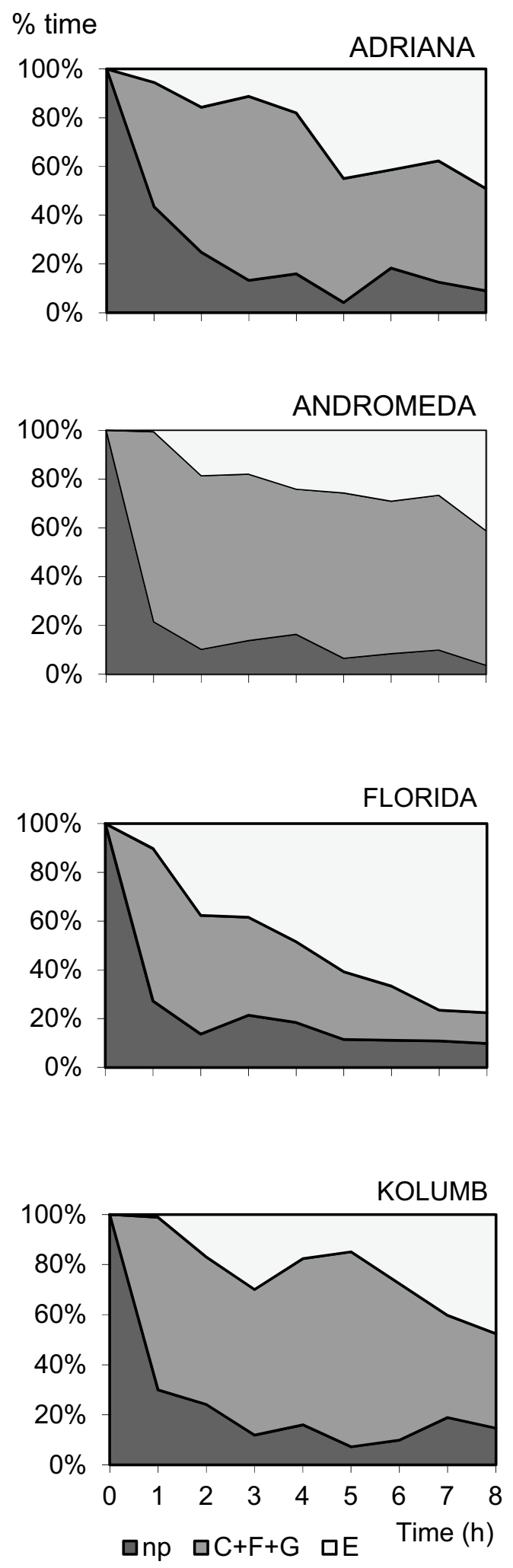

Fig. 2 Trends in Myzus persicae probing activities on Brassica napus cultivars studied, expressed as the proportion of time spent on different stylet activities during the 8 -h experiment: $\mathrm{np}$, non-probing;
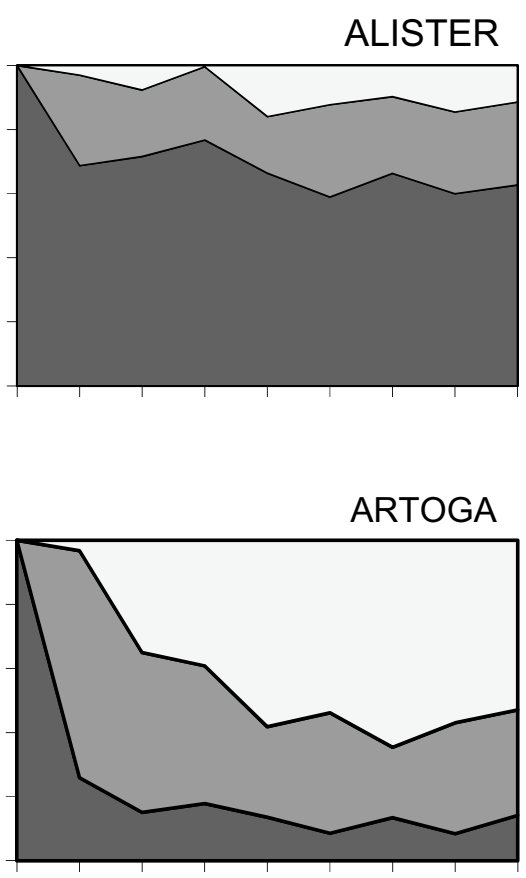

GLADIUS

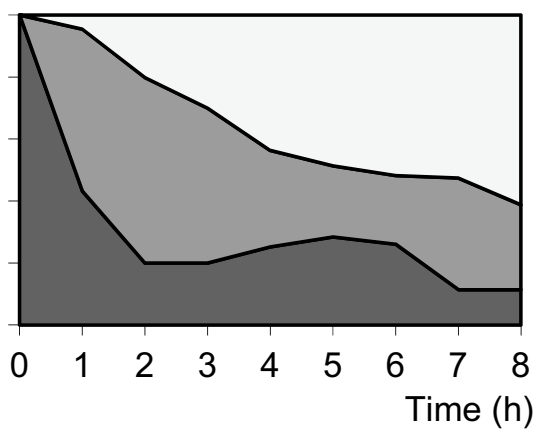

Proportion (\%) probing activities during 8-hour recording

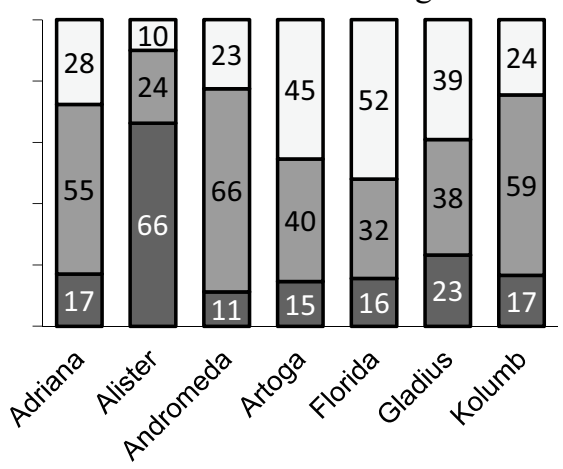

$C+G+F$, probing in non-phloem tissues (probing in non-vascular tissues + derailed stylet activities + xylem phase), $E$, total phloem phase $(E 1+E 2$, watery salivation + sap ingestion) 
Table 2 Probing behavior of Myzus persicae on oilseed rape Brassica napus cultivars studied

\begin{tabular}{|c|c|c|c|c|c|c|c|c|}
\hline & Adriana & Alister & Andromeda & Artoga & Florida & Gladius & Kolumb & $p$ \\
\hline $\begin{array}{l}\text { General aspects of aphid } \\
\text { probing behavior }\end{array}$ & $n=13$ & $n=12$ & $n=12$ & $n=12$ & $n=12$ & $n=15$ & $n=10$ & \\
\hline $\begin{array}{l}\text { Total non-probing time } \\
\text { (h) }\end{array}$ & $1.4 \pm 0.5 \mathrm{ab}$ & $5.3 \pm 2.8 \mathrm{a}$ & $0.9 \pm 1.0 \mathrm{~b}$ & $1.2 \pm 1.2 b$ & $1.2 \pm 2.1 \mathrm{~b}$ & $1.9 \pm 1.8 \mathrm{ab}$ & $1.3 \pm 1.1 \mathrm{ab}$ & 0.0000 \\
\hline $\begin{array}{l}\text { Total probing in non- } \\
\text { phloem tissues (h) }\end{array}$ & $4.3 \pm 1.7 \mathrm{ab}$ & $1.9 \pm 1.8 \mathrm{a}$ & $5.3 \pm 2.4 b$ & $3.2 \pm 1.8 \mathrm{ab}$ & $2.6 \pm 1.4 \mathrm{ab}$ & $3.0 \pm 2.0 \mathrm{ab}$ & $4.7 \pm 1.7 b$ & 0.0013 \\
\hline Total phloem phase (h) & $2.2 \pm 1.9 \mathrm{ab}$ & $0.8 \pm 1.7 \mathrm{~b}$ & $1.8 \pm 2.5 \mathrm{ab}$ & $3.6 \pm 2.0 \mathrm{a}$ & $4.2 \pm 2.0 \mathrm{a}$ & $3.1 \pm 2.5 \mathrm{a}$ & $2.0 \pm 1.6 \mathrm{ab}$ & 0.0002 \\
\hline $\begin{array}{l}\text { Proportion of phloem } \\
\text { phase in total probing }\end{array}$ & $0.3 \pm 0.3 a b$ & $0.1 \pm 0.2 b$ & $0.3 \pm 0.3 \mathrm{ab}$ & $0.5 \pm 0.3 \mathrm{a}$ & $0.6 \pm 0.3 \mathrm{a}$ & $0.5 \pm 0.3 \mathrm{a}$ & $0.3 \pm 0.2 \mathrm{ab}$ & 0.0001 \\
\hline Number of probes & $38.8 \pm 24.3 \mathrm{a}$ & $78.5 \pm 45.3 \mathrm{a}$ & $29.3 \pm 20.4 \mathrm{ab}$ & $16.6 \pm 17.4 b$ & $28.7 \pm 17.1 \mathrm{ab}$ & $11.7 \pm 7.8 b$ & $21.0 \pm 9.7 \mathrm{ab}$ & 0.0000 \\
\hline Duration of 1 st probe $(h)$ & $0.1 \pm 0.1 \mathrm{ab}$ & $0.0 \pm 0.0 \mathrm{~b}$ & $0.1 \pm 0.2 \mathrm{ab}$ & $0.9 \pm 2.3 \mathrm{a}$ & $0.7 \pm 2.3 \mathrm{ab}$ & $0.9 \pm 2.0 \mathrm{ab}$ & $0.4 \pm 0.7 \mathrm{a}$ & 0.0027 \\
\hline $\begin{array}{l}\text { Mean duration of a probe } \\
(\min )\end{array}$ & $10.3 \pm 33.4 \mathrm{~cd}$ & $2.1 \pm 16.8 \mathrm{a}$ & $14.6 \pm 49.3 d$ & $24.8 \pm 78.0 \mathrm{bcd}$ & $14.1 \pm 50.7 \mathrm{bc}$ & $31.6 \pm 77.6 \mathrm{bcd}$ & $19.2 \pm 42.9 d$ & 0.0000 \\
\hline $\begin{array}{l}\text { Mean duration of non- } \\
\text { probing intervals (min) }\end{array}$ & $2.1 \pm 4.7 \mathrm{de}$ & $4.1 \pm 9.3 \mathrm{ab}$ & $1.8 \pm 6.5 f$ & $4.1 \pm 19.7 \mathrm{~cd}$ & $2.2 \pm 8.2 \mathrm{ef}$ & $6.8 \pm 24.9 \mathrm{bcd}$ & $3.7 \pm 12.8 \mathrm{cde}$ & 0.0000 \\
\hline \multicolumn{9}{|c|}{ Aphid behavior in non-phloem tissues prior to the 1st phloem phase } \\
\hline $\begin{array}{l}\text { Number of probes before } \\
\text { 1st phloem phase }\end{array}$ & $14.7 \pm 12.7 \mathrm{ab}$ & $72.5 \pm 52.3 \mathrm{a}$ & $12.1 \pm 10.3 \mathrm{ab}$ & $7.0 \pm 4.4 \mathrm{~b}$ & $13.7 \pm 6.8 \mathrm{ab}$ & $6.7 \pm 5.4 b$ & $13.2 \pm 6.3 \mathrm{ab}$ & 0.0000 \\
\hline $\begin{array}{l}\text { Time from 1st probe to } \\
1 \text { st phloem phase }(\mathrm{h})\end{array}$ & $2.1 \pm 1.2 \mathrm{ab}$ & $6.4 \pm 2.9 \mathrm{a}$ & $2.6 \pm 2.7 \mathrm{ab}$ & $1.7 \pm 1.2 \mathrm{ab}$ & $1.6 \pm 1.7 \mathrm{~b}$ & $2.2 \pm 2.1 \mathrm{ab}$ & $3.7 \pm 2.3 \mathrm{ab}$ & 0.0003 \\
\hline $\begin{array}{l}\text { Time from 1st probe to } \\
1 \text { st sustained sap inges- } \\
\text { tion period (h) }\end{array}$ & $4.2 \pm 2.5 \mathrm{ab}$ & $6.8 \pm 2.8 \mathrm{a}$ & $5.0 \pm 3.2 \mathrm{ab}$ & $2.3 \pm 2.0 \mathrm{~b}$ & $2.4 \pm 1.7 \mathrm{~b}$ & $3.3 \pm 2.6 \mathrm{ab}$ & $4.4 \pm 2.4 \mathrm{ab}$ & 0.0007 \\
\hline $\begin{array}{l}\text { Total duration of non- } \\
\text { probing before } 1 \mathrm{st} \\
\text { phloem phase (h) }\end{array}$ & $0.6 \pm 0.4 \mathrm{ab}$ & $5.2 \pm 3.0 \mathrm{a}$ & $1.0 \pm 2.3 b$ & $0.3 \pm 0.3 b$ & $0.7 \pm 1.5 b$ & $0.4 \pm 0.6 b$ & $0.7 \pm 0.8 \mathrm{ab}$ & 0.0000 \\
\hline $\begin{array}{l}\text { Mean duration of non- } \\
\text { probing intervals (min) }\end{array}$ & $2.2 \pm 5.9 \mathrm{de}$ & $4.3 \pm 9.6 \mathrm{ab}$ & $1.5 \pm 5.6 \mathrm{f}$ & $5.6 \pm 27.4 \mathrm{cdef}$ & $2.9 \pm 11.2 \mathrm{ef}$ & $4.0 \pm 8.7 \mathrm{bcd}$ & $3.0 \pm 10.3 \mathrm{ef}$ & 0.0000 \\
\hline $\begin{array}{l}\text { Aphid behavior during } \\
\text { phloem phase }\end{array}$ & $n=13$ & $n=3$ & $n=11$ & $n=12$ & $n=11$ & $n=14$ & $n=10$ & \\
\hline $\begin{array}{l}\text { Duration of 1st phloem } \\
\text { phase (h) }\end{array}$ & $1.0 \pm 2.1$ & $0.4 \pm 0.6$ & $0.8 \pm 2.1$ & $1.8 \pm 2.2$ & $1.1 \pm 2.3$ & $2.3 \pm 2.8$ & $1.3 \pm 1.2$ & 0.1487 \\
\hline $\begin{array}{l}\text { Duration of 1st ingestion } \\
\text { phase (h) }\end{array}$ & $0.4 \pm 1.2$ & $0.4 \pm 0.6$ & $1.3 \pm 2.4$ & $1.8 \pm 2.2$ & $1.2 \pm 2.2$ & $2.5 \pm 2.9$ & $1.3 \pm 1.2$ & 0.0971 \\
\hline $\begin{array}{l}\text { Proportion of salivation in } \\
\text { phloem phase }\end{array}$ & $0.1 \pm 0.1$ & $0.2 \pm 0.3$ & $0.3 \pm 0.4$ & $0.0 \pm 0.0$ & $0.1 \pm 0.2$ & $0.1 \pm 0.3$ & $0.1 \pm 0.1$ & 0.0677 \\
\hline
\end{tabular}

Values are means $( \pm \mathrm{SD}), n=$ number of replications analyzed. Different letters in rows show significant differences at $p<0.05$ (Kruskal-Wallis test and post hoc multiple comparisons of mean ranks for all groups Dunn's test)

Non-probing intervals were the shortest on 'Andromeda' and the longest on 'Gladius' (1.8-6.8 min) (Table 2).

Time to 1 st phloem phase from the onset of probing was the shortest on 'Florida' $(1.6 \pm 1.7 \mathrm{~h})$ and 'Artoga' $(1.7 \pm 1.2 \mathrm{~h})$ and the longest on 'Alister' $6.4 \pm 2.9 \mathrm{~h})$. On 'Florida' and 'Artoga', time to reach 1st sustained (E2 $>10 \mathrm{~min}$ ) sap ingestion period was the shortest. On 'Artoga' and 'Gladius', the total time of non-probing activities before first phloem phase was the shortest $(25 \%$ and $21 \%$ of total non-probing time, respectively) and the longest on 'Alister' (98\%). Number of probes before 1st phloem phase was the lowest in aphids on 'Artoga' and 'Gladius' (7.0 \pm 4.4 and $6.7 \pm 5.4$, respectively) and the highest on 'Alister' $(72.5 \pm 52.3)$. These probes were separated by non-probing intervals, which were the shortest $(1.5 \pm 5.6 \mathrm{~min})$ on 'Andromeda' and the longest on 'Artoga' $(5.6 \pm 27.4 \mathrm{~min})$ (Table 2).

On 'Adriana', 'Artoga' and 'Kolumb', all aphids achieved phloem phase and all showed sap ingestion activity (Figs. 3, S3). On 'Florida', 92\% of aphids showed periods of sustained sap ingestion, while on 'Andromeda' and 'Gladius', $92 \%$ and $93 \%$ of aphids showed phloem phase, but $83 \%$ and $87 \%$ of aphids on these cultivars showed sap ingestion activity, respectively. On 'Alister', only $25 \%$ of aphids attained phloem phase and sap ingestion phase during the 8-h experiment (Figs. 3, S3). The duration of 1st phloem phase did not differ significantly among aphids, but there was a visible trend: the first phloem phase was the shortest on 'Alister' 
Fig. 3 Cumulative proportion of Myzus persicae reaching phloem phase on Brassica napus cultivars studied

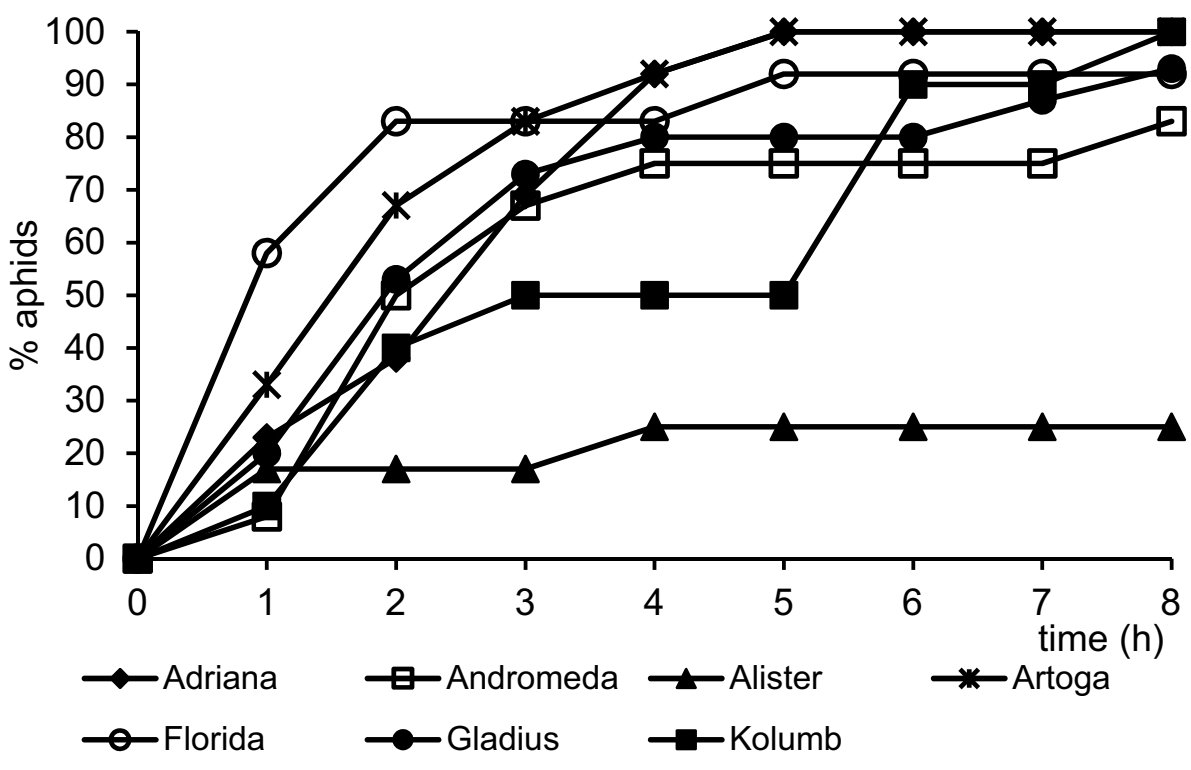

and the longest on 'Gladius'. Similar trend occurred in the duration of the first sap ingestion phase: it was the longest on 'Gladius' and the shortest on 'Adriana' and 'Alister' with aphids on other cultivars showing intermediate values of this parameter (Table 2). The proportion of E1 salivation during phloem phase was relatively high in all cultivars (from $10 \%$ on 'Artoga' to $30 \%$ on 'Andromeda'), but did not differ significantly among aphids (Table 2).

\section{Glucosinolate content}

Total amount of glucosinolates in leaves of oilseed rape cultivars studied ranged from $1.834 \pm 0.049 \mu \mathrm{mol} / \mathrm{g}$ dry weight (d.w.) in 'Andromeda' to 3.229 $\pm 0.061 \mu \mathrm{mol} / \mathrm{g} \mathrm{d}$.w. in 'Alister'. No qualitative differences occurred among the cultivars. Seven glucosinolates were found: aliphatic glucoallysin, glucobrassicanapin, gluconapin, gluconapoliferin and progoitrin and indole glucobrassicin and 4-OH-glucobrassicin
(Table 3). In total, aliphatic glucosinolates predominated, whose amount ranged from $61 \%$ of all glucosinolates in 'Gladius' to 74\% in 'Alister'. In all cultivars, glucobrassicanapin and progoitrin, and 4-OH-glucobrassicin were the most abundant (Figure S4).

\section{Correlation analysis}

The correlation analysis revealed significant relationships among the aphid probing behavior parameters studied. Positive correlations occurred (1) between the total duration of non-probing and the total number of probes, number of probes before 1st phloem phase, time from 1 st probe to 1 st phloem phase, and total duration of non-probing before 1 st phloem phase, (2) between the total duration of phloem phase and the proportion of phloem phase in total probing and the duration of 1 st probe, (3) between the proportion of phloem phase in total probing and the duration of $1 \mathrm{st}$

Table 3 Glucosinolate profiles of oilseed rape Brassica napus cultivars studied

\begin{tabular}{llllllll}
\hline & Adriana & Alister & Andromeda & Artoga & Florida & Gladius & Kolumb \\
\hline Aliphatic & & & & & & & \\
Glucoallysin & $0.106 \pm 0.001$ & $0.243 \pm 0.001$ & $0.066 \pm 0.004$ & $0.117 \pm 0.006$ & $0.250 \pm 0.004$ & $0.049 \pm 0.001$ & $0.064 \pm 0.000$ \\
Glucobrassicanapin & $0.486 \pm 0.006$ & $0.619 \pm 0.019$ & $0.371 \pm 0.018$ & $0.441 \pm 0.001$ & $0.419 \pm 0.021$ & $0.573 \pm 0.021$ & $0.523 \pm 0.023$ \\
Gluconapin & $0.184 \pm 0.006$ & $0.154 \pm 0.007$ & $0.109 \pm 0.005$ & $0.357 \pm 0.010$ & $0.108 \pm 0.008$ & $0.180 \pm 0.011$ & $0.120 \pm 0.010$ \\
Gluconapoliferin & $0.098 \pm 0.004$ & $0.251 \pm 0.011$ & $0.059 \pm 0.004$ & $0.099 \pm 0.001$ & $0.130 \pm 0.006$ & $0.047 \pm 0.000$ & $0.068 \pm 0.004$ \\
Progoitrin & $0.556 \pm 0.024$ & $1.051 \pm 0.031$ & $0.659 \pm 0.003$ & $0.759 \pm 0.016$ & $1.083 \pm 0.013$ & $0.570 \pm 0.009$ & $0.650 \pm 0.004$ \\
Indole & & & & & & \\
Glucobrassicin & $0.079 \pm 0.011$ & $0.106 \pm 0.003$ & $0.095 \pm 0.001$ & $0.094 \pm 0.007$ & $0.059 \pm 0.004$ & $0.046 \pm 0.006$ & $0.079 \pm 0.005$ \\
4-OH-glucobrassicin & $0.860 \pm 0.005$ & $0.806 \pm 0.011$ & $0.477 \pm 0.023$ & $0.858 \pm 0.038$ & $0.862 \pm 0.025$ & $0.887 \pm 0.038$ & $0.814 \pm 0.005$ \\
Total & $2.368 \pm 0.017$ & $3.229 \pm 0.061$ & $1.834 \pm 0.049$ & $2.723 \pm 0.065$ & $2.910 \pm 0.046$ & $2.351 \pm 0.075$ & $2.317 \pm 0.015$ \\
\hline
\end{tabular}

Values are means $( \pm \mathrm{SD}), \mu \mathrm{M} / \mathrm{g}$ dry weight 
probe, (4) between the number of probes and the number of probes before 1st phloem phase, time from 1st probe to 1st phloem phase, time from 1st probe to 1 st sustained sap ingestion period and total duration of non-probing before 1st phloem phase, (5) between the number of probes before 1st phloem phase and time from 1st probe to 1 st phloem phase, time from 1st probe to 1st sustained sap ingestion period and total duration of non-probing before 1 st phloem phase, (6) between time from 1st probe to 1st phloem phase and time from 1st probe to 1 st sustained sap ingestion period and (7) between time from 1st probe to 1st sustained sap ingestion period and total duration of non-probing before $1 \mathrm{st}$ phloem phase. Negative correlations occurred (1) between the total duration of phloem phase and time from 1st probe to 1 st phloem phase and time from 1st probe to 1st sustained sap ingestion period, (2) between the proportion of phloem phase in total probing and time from 1st probe to 1st phloem phase and time from 1st probe to 1st sustained sap ingestion period and (3) between the duration of 1st probe and time from 1st probe to 1 st sustained sap ingestion period (Table S1).

The correlation analysis revealed also significant positive relationships between traits of $M$. persicae probing behavior and glucosinolate content in leaves of $B$. napus cultivars studied. Most notably, the values of aphid total non-probing, total non-probing before the first phloem phase, number of probes and number of probes before the first phloem phase were positively related to the concentration of gluconapoliferin. Total duration of non-probing was also positively correlated with glucobrassicanapin concentration. None of aphid probing behavior traits was correlated with the total amount of glucosinolates in plant leaves (Table S1).

Distribution of winter oilseed rape cultivars in terms of the first two principal components of seven aphid life table observed traits is presented in Figure S5. The first two principal components accounted for $98.34 \%$ of total multivariate variability between winter oilseed rape cultivars. The greatest, significant linear relationship with the first principal component was found for reproduction period, net reproduction R0, daily fecundity (positive dependencies) and post-reproduction period and $\mathrm{Md} / \mathrm{R} 0$ (negative). The second principal component was significantly positively correlated with aphid longevity (Figure S5).

Distribution of winter oilseed rape cultivars in terms of the first two principal components of nine aphid probing observed traits is presented in Figure S6. The first two principal components accounted for $97.59 \%$ of total multivariate variability between winter oilseed rape cultivars. The first principal component was significantly positively correlated with total non-probing, number of probes, number of probes before $1 \mathrm{st}$ phloem phase, time from 1st probe to $1 \mathrm{st}$ phloem phase, time from 1st probe to 1 st sustained sap ingestion period and total duration of non-probing before 1 st phloem phase; PC1 was significantly negatively correlated with total phloem phase and proportion of phloem phase in total probing (Figure S6).

Distribution of winter oilseed rape cultivars in terms of the first two principal components of eight glucosinolate content observed traits is presented in Figure S7. The first two principal components accounted for $95.17 \%$ of total multivariate variability between winter oilseed rape cultivars. The first principal component was significantly positively correlated with progoitrin, glucoallysin, gluconapoliferin and total glucosinolates (Figure S7).

\section{Discussion}

The present assessment of the rapeseed cultivars susceptibility to $M$. persicae infestation was based on two lines of inquiry. First, aphid probing and feeding were evaluated in relation to qualitative and quantitative content of glucosinolates. Plant secondary chemistry is among the most important mechanisms that determine host plant suitability to aphids (Douglas 2003; van Emden 2017). This line of study was designed to reveal antixenosis mechanisms in young plants that are particularly vulnerable to aphid infestation during the autumn period of winter rapeseed development. Second, we monitored M. persicae development in concurrence with rapeseed growth to expose antibiosis mechanisms in these plants.

The differences in aphid probing behavior observed in the present study indicate the existence of antixenosis mechanisms in certain oilseed rape cultivars. Aphids can distinguish a host from a non-host as soon as at the level of epidermis and/or parenchyma (Martin et al. 1997; Gabryś and Pawluk 2000; Gabryś and Tjallingii 2002). A high proportion of probing in non-phloem tissues in relation to total penetration time, long time to first phloem phase and a failure to find sieve elements are interpreted as effects of mechanisms that restrain probing in the non-phloem tissues and reflect antixenosis potential in these tissues (Pettersson et al. 2017; van Emden 2017; Kordan et al. 2018, 2019). There was a clear effect of antixenosis mechanisms in nonphloem tissues in 'Alister', on which the aphids had evident difficulties in reaching phloem vessels. The average time to reach sieve elements and start ingestion by $M$. persicae on Chinese cabbage, the plant the stock colony was kept, is approximately $2.4 \mathrm{~h}$ (Wróblewska-Kurdyk et al. 2019). In the present study, a similar or shorter time before the commencement of the phloem phase occurred in all aphids on all cultivars, except 'Alister', where aphids took almost threefold more time to reach sieve elements. Correlation analysis showed that the time from 1st probe to 1 st phloem phase is strongly affected by total duration of non-probing and the number of probes before 1 st phloem phase, which means 
that M. persicae on 'Alister' was reluctant to probe and when it did probe, the probes were numerous and of short duration. In contrast, on 'Adriana', 'Artoga' and 'Kolumb', all aphids achieved phloem phase and all showed sap ingestion activity in a relatively short time, which demonstrates the absence of antixenosis mechanisms in non-phloem leaf tissues of these cultivars. The presence of antixenosis mechanisms in non-phloem leaf tissues of 'Andromeda', 'Florida' and 'Gladius' can also be excluded. Although some aphids failed to locate phloem on these cultivars during the 8-h experiment, the overall success rates in finding sieve elements and in the duration of feeding were relatively high and did not differ significantly from those on 'Adriana', 'Artoga' and 'Kolumb'.

The glucosinolate spectrum in all oilseed rape cultivars studied was typical of this species (Ishida et al. 2014). The total content of glucosinolates in the leaves of all cultivars of winter oilseed rape studied was relatively low, and the cultivars did not differ in the content of individual compounds. In the present study, the duration of non-probing was generally positively correlated with the concentration of gluconapoliferin. Gluconapoliferin occurred in all rapeseed cultivars studied but in low amounts and its share in the total spectrum ranged from $2.0 \%$ in 'Gladius' to $7.8 \%$ in 'Alister'. The glucosinolate system in brassicaceous plants is dynamic. The quantitative as well as qualitative content of glucosinolates varies depending on species, variety and cultivar (Kjaer 1976). Moreover, the concentration of individual compounds of the species/cultivar-specific glucosinolate combination is different in different tissues and organs of the plant and depends on the developmental stage (McGregor 1988, Bodnaryk 1991; Merritt 1996; Gabryś et al. 1997; Halkier and Gershenzon 2006; Hong and Kim 2014). Glucosinolates are present in all plant compartments: on leaf surface, in apoplast, in epidermis and mesophyll cells, and in sieve elements (Matile 1984; Renwick et al. 1992; Brudenell et al. 1999; Chen et al.2001). In sieve elements, the concentration of glucosinolates is similar to that reported for leaf extracts (Merritt 1996). Toxic to unspecialized insects (Feeny 1977), the glucosinolates stimulate the feeding of the cabbage aphid Brevicoryne brassicae (L.) (Hemiptera: Aphididae), which depends exclusively on brassicas (Gabryś and Tjallingii 2002). However, the probability of B. brassicae infestation decreases with the increasing concentrations of progoitrin in plants (Goodey et al. 2015). At low concentrations, glucosinolates can be tolerated by some polyphagous insects, such as peach potato aphid, and under certain conditions they even increase plant suitability to M. persicae (Nault and Styer 1972). The ubiquity of glucosinolates in the plant organism makes them easily detectable to aphids at every probing phase, in non-phloem as well as in phloem tissues (Gabryś and Tjallingii 2002). Generally, glucosinolates do not affect the consumption of phloem sap by M. persicae
(Cole 1997b). In yellow mustard Sinapis alba L., M. persicae ingested sap from as many sieve elements in stems as in the old leaves, and there was no difference in the time spent on the phloem sap ingestion, although in stems, the total amount of glucosinolates was nearly five times higher than in old leaves (Gabryś et al. 1997; Gabryś and Tjallingii 2000). When selecting the feeding site, M. persicae appears to be dependent mainly on the nutritional quality of the sap (van Emden and Bashford 1969; Klingauf 1987). M. persicae can survive the consumption of considerable amount of glucosinolates and excretes these allelochemicals unaltered in honeydew (Weber et al. 1986). Although glucosinolates are present in peripheral plant tissues and in the phloem sap (Douglas 2003), the deterrent effect of these compounds on M. persicae probing on rapeseed cultivars may be excluded. It is likely that glucosinolates were not responsible for the varied level of susceptibility of oilseed rape cultivars to $M$. persicae in the present study. The rate of phloem sap uptake is constant, so the duration of feeding periods reflects the amount of sap consumed (Tjallingii 1995; Pettersson et al. 2017). The disruption of aphid feeding, visualized as short total and mean durations of sap ingestion and high proportion of $E 1$ salivation during phloem phase, points at the activity of antixenosis mechanisms in sieve elements (van Helden and Tjallingii 1993; Mayoral et al. 1996; Wilkinson and Douglas 1998; Pettersson et al. 2017; van Emden 2017; Kordan et al. 2018, 2019). The durations of ingestion in aphids on 'Andromeda', 'Florida', 'Gladius', 'Adriana', 'Artoga' and 'Kolumb' were relatively high, which suggests the absence of antixenosis mechanisms in the phloem sap in these cultivars. It may be conferred from the duration of ingestion that the quantities of the consumed sap by aphids on 'Andromeda', 'Florida', 'Gladius', 'Adriana', 'Artoga' and 'Kolumb' were generally similar. The inability to reach phloem vessels in at least $8 \mathrm{~h}$, which was the duration of the EPG experiment, might have caused undernourishment in aphids on 'Alister'. Nevertheless, the antixenosis mechanisms in 'Alister' remain unknown until a further study on plant chemistry is carried out.

The analysis of aphid bionomics showed interesting similarities and differences in aphid development and reproduction on rapeseed cultivars studied. The duration of pre-reproductive period did not differ among aphids on all rapeseed cultivars and lasted approximately two weeks. The pre-reproductive development of $M$. persicae depends on many mechanisms, including temperature, host plant species, developmental stage of the plant and may vary from 6-7 days on Capsicum annum (Birgucu and Bayindir-Erol 2018), 10-11 days on Solanum tuberosum (Alla et al. 2003), up to 12 days on Brassica caber (Fernandez-Quintanilla et al. 2002). Additionally, maternal environment has an important influence on the performance of aphid offspring (McLean et al. 2009). The nymphs in the present study were 
born by females that spent their life in stock cultures maintained on the suitable host plant. It is very likely that the transfer from a different plant and the necessity to adjust to the new plant by all aphids on all rapeseed cultivars studied caused an elongation of the pre-reproductive period, which, as a result, appeared similar in all aphids. The intrinsic rate of increase $\left(r_{m}\right)$ was also similar in all cultivars, which might have indicated their equal suitability to $M$. persicae infestation. The explanation is in the way of calculating the $r_{m}$. The value of $r_{m}$ depends basically on two aspects, the duration of the pre-reproductive period $(D)$ and the assumption that a reproducing female gives birth to $95 \%$ of her progeny in the first $D$ days of reproduction (Leather et al. 2017). This assumption has an important bearing on the value of $r_{m}$ and not always reflects plant suitability (Leather et al. 2017), which was the case in the present study. The duration of $D$ was similar in all $M$. persicae on all oilseed rape cultivars studied, but the $95 \%$ reproduction in the $D$ period was never reached on any oilseed rape cultivar studied. The closest to this value was the reproduction in aphids on 'Alister', 'Florida' and to a lesser degree on 'Kolumb' (77\%, 75\%, and $68 \%$, respectively), while on other cultivars, the reproduction was more 'regular' and occurred essentially in all aphids throughout the whole adult life. Considering these drawbacks, we decided to focus on the reproductive activity of aphids in the assessment of rapeseed cultivars, namely the duration of the reproductive period, net reproduction and the number of nymphs born in the first $D$ days of reproduction.

Myzus persicae had longest lifetime duration and survival on 'Alister' but the lowest fecundity and the shortest reproductive period as compared to aphids on the remaining cultivars studied, which means that $M$. persicae is able to develop a population but only to a limited degree. Considering the possible changes in plant characteristic during the experiment, the effect of other than glucosinolate-based, unknown mechanisms, on M. persicae development on 'Alister' cannot be excluded. As commented earlier, the duration of feeding periods reflects the amount of sap consumed. The similar relatively high performance of $M$. persicae could have been attributed to unaltered rate of consumption of sap on 'Andromeda', 'Gladius', 'Adriana', 'Artoga' and 'Kolumb', but not on 'Florida'. On 'Florida', the performance of $M$. persicae was surprisingly poor despite high amounts of the consumed sap, as inhibition of sap consumption did not occur in aphids on 'Florida'. We are still investigating what mechanisms are behind the low performance of $M$. persicae on 'Florida', but it is very likely that the low nutritional value of the phloem sap was responsible for the reduced aphid fecundity on this cultivar. Further studies on phloem sap composition in the rapeseed cultivars will be required to confirm this hypothesis.

The statistical analysis (PCA), performed independently for aphid probing, development and plant chemistry, showed no similarities in the groupings of rapeseed cultivars studied. Therefore, no unequivocal classification of cultivars that would have included all analyzed traits was possible. Nevertheless, taking into account aphid performance, probing behavior and plant secondary chemistry, the winter oilseed rape cultivars studied can be categorized according to $M$. persicae preferences and the assumed backgrounds of these preferences. Group I-least susceptible- 'Alister' and 'Florida'. In 'Alister', antixenosis mechanisms exist in non-phloem tissues, which prevent $M$. persicae from locating phloem vessels. In 'Florida', probably antibiosis mechanisms exist in the phloem or the phloem sap is of low nutritional value, either or both of which may cause a reduction in reproductive activity of $M$. persicae. Group IIintermediately susceptible — 'Adriana', 'Andromeda', 'Gladius', 'Kolumb' - on which net reproduction of M. persicae was higher than on 'Alister' and 'Florida' and lower than on 'Artoga'. No clear antixenosis and antibiosis mechanisms were detected in these cultivars although a minor disruption in sap uptake was observed. Group III-highly susceptible'Artoga' - longest reproduction, highest daily fecundity and net reproduction. Neither antixenosis nor antibiosis was detected in this cultivar. Glucosinolates found in the leaves of the rapeseed cultivars studied did not affect the peach potato aphid probing and feeding. From the practical point of view, B. napus cv. 'Alister' appears the most promising in respect of $M$. persicae control. The antixenosis mechanisms against $M$. persicae predicted in this cultivar are worth further studies, especially considering the prevention of plant virus transmission. Aphids acquire and inoculate semi-persistent and non-persistent viruses during brief probes in nonphloem tissues along the stylets' route to the phloem (Martin et al. 1997), while persistent viruses are transmitted during the access to sieve elements (Prado and Tjallingii 1994). The deterrence of aphid probing at the level of epidermis and/ or outer layers of mesophyll may reduce yield losses due to aphid feeding and limit the spread of plant virus diseases.

In conclusion, two mechanisms of defense against M. persicae (antixenosis and antibiosis) were identified among the cultivars of B. napus. Depending on a cultivar, these mechanisms affected different phases of aphid probing and feeding behaviors and reproduction. Antixenosis in B. napus caused the disruption in probing in non-phloem tissues and a failure in reaching sieve elements, while antibiosis impeded the reproductive activity of $M$. persicae. Glucosinolates identified in the leaves of B. napus did not affect M. persicae performance, sieve element finding and sap ingestion activity. There was no knowledge on the background of susceptibility or resistance of rapeseed cultivars to $M$. persicae infestation in Poland and in Europe, prior to our study. The results of our survey provide the first detailed data that can be used for reference studies in the future. 
Author contributions BK performed experiments on aphid development; AW-K, KS, BG contributed to EPG experiments; KJ helped in glucosinolate analysis; JB statistically analyzed the study; and BG wrote the manuscript. All authors read and approved the manuscript.

\section{Compliance with ethical standards}

Conflict of interest The authors declare that they have no conflict of interest.

Open Access This article is licensed under a Creative Commons Attribution 4.0 International License, which permits use, sharing, adaptation, distribution and reproduction in any medium or format, as long as you give appropriate credit to the original author(s) and the source, provide a link to the Creative Commons licence, and indicate if changes were made. The images or other third party material in this article are included in the article's Creative Commons licence, unless indicated otherwise in a credit line to the material. If material is not included in the article's Creative Commons licence and your intended use is not permitted by statutory regulation or exceeds the permitted use, you will need to obtain permission directly from the copyright holder. To view a copy of this licence, visit http://creativecommons.org/licenses/by/4.0/.

\section{References}

Ackman RG (1990) Canola fatty acids - an ideal mixture for health, nutrition, and food use. In: Shahidi F (ed) Canola and rapeseed. Springer, Boston, pp 81-98

Ahuja I, Rohloff J, Bones AM (2010) Defence mechanisms of Brassicaceae: implications for plant-insect interactions and potential for integrated pest management. Rev Agron Sustain Dev 30:311-348

Alla S, Cherqui A, Kaiser L, Azzouz H, Sangwann-Norreel BS, Giordanengo P (2003) Effects of potato plants expressing the nptII-gus fusion marker genes on reproduction, longevity, and host-finding of the peach-potato aphid, Myzus persicae. Entomol Exp Appl 106:95-102

Awmack CS, Leather SR (2002) Host plant quality and fecundity in herbivorous insects. Annu Rev Entomol 47:817-844

Bale JS, Harrington R, Clough MS (1988) Low temperature mortality of the peach-potato aphid Myzus persicae. Ecol Entomol 13:121-129

Bass C, Puinean AM, Zimmre CT, Denholm I, Field LM, Foster SP, Gutbrod O, Nauen R, Slater R, Williamson MS (2014) The evolution of insecticide resistance in the peach potato aphid Myzus persicae. Insect Biochem Mol Biol 51:41-51

Beer K, Joschinski J, Sastre AA, Kraus J, Helfrich-Forster C (2017) A damping circadian clock drives weak oscillations in metabolism and locomotor activity of aphids (Acyrthosiphon pisum). Sci Rep 7:1-5. https://doi.org/10.1038/s41598-017-15014-3

Birgucu AK, Bayindir-Erol A (2018) Maternal age effect on biology of aphids: a lifetable approaches. Fresen Environ Bull 27:7470-7478

Blackman RL, Eastop VF (2017) Taxonomic issues. In: van Emden HF, Harrington R (eds) Aphids as crop pests. CABI, Wallingford, pp 1-36

Bodnaryk R (1991) Developmental profile of synalbin (p-hydroxybenzyl glucosinolate) in mustard seedlings, Sinapis alba L., and its relationship to insect resistance. J Chem Ecol 17:1543-1556

Brader G, Mikkelsen MD, Halkier BA, Palva T (2006) Altering glucosinolate profiles modulates disease resistance in plants. Plant J 46:758-767

Brudenell AJP, Griffiths H, Rossiter JT, Baker DA (1999) The phloem mobility of glucosinolates. J Exp Bot 50:745-756
Bundessortenamt (2014) Beschreibende Sortenliste. Getreide, Mais, Öl- und Faserpflanzen, Leguminosen, Rüben, Zwischenfrüchte. Bundessortenamt, Hannover

Chen SX, Petersen BL, Olsen CE, Schulz A, Halkier BA (2001) Longdistance phloem transport of glucosinolates in Arabidopsis. Plant Physiol 127:194-201

Ciska E, Honke J, Kozłowska H (2008) Effect of light conditions on the contents of glucosinolates in germinating seeds of white mustard, red radish, white radish and rapeseed. J Agric Food Chem 56:9087-9093

Cocu N, Harrington R, Rounsevell MDA, Worner SP, Hulle M (2005) Geographical location, climate and land use influences on the phenology and numbers of the aphid, Myzus persicae, in Europe. J Biogeogr 32:615-632

Cole RA (1997a) The relative importance of glucosinolates and amino acids to the development of two aphid pests Brevicoryne brassicae and Myzus persicae on wild and cultivated brassica species. Entomol Exp Appl 85:121-133

Cole RA (1997b) Comparison of feeding behaviour of two Brassica pests Brevicoryne brassicae and Myzus persicae on wild and cultivated brassica species. Entomol Exp Appl 85:135-143

Commission of the European Communities (1990). Commission Regulation (EC) No 1864/90 of 29 June 1990 amending Regulation (EEC) No 147/68 on the drawing and reduction of samples and on methods of analysis in respect of oil seed. Brussels. Official Journal of the European Communities. L 170/27-L 170/34.

Dewar AM (2017) The adverse impact of the neonicotinoid seed treatment ban on crop protection in oilseed rape in the United Kingdom. Pest Manag Sci 73:1305-1309

Douglas A (2003) The nutritional physiology of aphids. In: Simpson SJ (ed) Advances in insect physiology. Elsevier, Amsterdam, pp $73-140$

Drizou F, Bruce TJA, Rumiana VR, Graham NS (2018) Infestation by Myzus persicae increases susceptibility of Brassica napus cv. "Canard" to Rhizoctonia solani AG 2-1. Front Plant Sci 9:1903

Ekbom B (2010) Pests and their enemies in spring oilseed rape in Europe and challenges to integrated pest management. In: Williams IH (ed) Biocontrol-based integrated management of oilseed rape pests. Springer, New York, pp 151-165

FAOSTAT (2018) Food and agriculture organisation statistical database. https://www.apps.fao.org/. Accessed 28 Nov 2018

Fathi SAA, Nouri-Ganbalani G, Sadagati M (2010) Resistance of some canola cultivars to Myzus persicae (Hemiptera: Aphididae). Appl Entomol Zool 45:601-608

Feeny P (1977) Defensive ecology of the Cruciferae. Ann Missouri Bot Gard 64:221-234

Fernandez-Quintanilla C, Fereres A, Godfrey L, Norris RF (2002) Development and reproduction of Myzus persicae and Aphis fabae (Hom., Aphididae) on selected weed species surrounding sugar beet fields. J Appl Entomol 126:198-202

Friedt W, Snowdon R (2009) Oilseed rape. In: Vollmann J, Rajcan I (eds) Handbook of plant breeding. Oil crops. Springer, New York, pp 91-125

Gabryś B, Pawluk M (1999) Acceptability of different species of Brassicaceae as hosts for the cabbage aphid. Entomol Exp Appl 91:105-109

Gabryś B, Tjallingii WF (2000) Behavioural responses of Brevicoryne brassicae (L.) and Myzus persicae (Sulz.) (Homoptera, Aphididae) to glucosinolates in their host plant. Aphids Other Homopterous Insects 7:203-207

Gabryś B, Tjallingii WF (2002) The role of sinigrin in host plant recognition by aphids during initial plant penetration. Entomol Exp Appl 104:89-93

Gabryś B, Tjallingii WF, van Beek TA (1997) Analysis of EPG recorded probing by the cabbage aphid on host plant parts with different glucosinolate contents. J Chem Ecol 23:1661-1673 
Gabryś B, Dancewicz K, Gliszczyńska A, Kordan B, Wawrzeńczyk C (2015) Systemic deterrence of aphid probing and feeding by $\beta$-damascone analogues. J Pest Sci 88:507-516

Goodey NA, Florance HV, Smirnoff N, Hodgson DJ (2015) Aphids pick their poison: selective sequestration of plant chemicals affects host plant use in a specialist herbivore. J Chem Ecol 41:956-964

Halkier BA, Gershenzon J (2006) Biology and biochemistry of glucosinolates. Annu Rev Plant Biol 57:303-333

Hong E, Kim G-H (2014) Variation of glucosinolate composition during seedling and growth stages of Brassica rapa L. ssp. pekinensis. Hortic Sci Technol 32:730-738

Ishida M, Hara M, Fukino N, Kakizaki T, Morimitsu Y (2014) Glucosinolate metabolism, functionality and breeding for the improvement of Brassicaceae vegetables. Breed Sci 64:48-59

Jang SA, Lim GO, Song KB (2011) Preparation and mechanical properties of edible rapeseed protein films. J Food Sci 76:218-223

Jankowski KJ, Budzyński WS, Kijewski Ł (2015a) An analysis of energy efficiency in the production of oilseed crops of the family Brassicaceae in Poland. Energy 81:674-681

Jankowski KJ, Budzyński WS, Kijewski Ł, Zając T (2015b) Biomass quality of Brassica oilseed crops in response to sulfur fertilization. Agron J 4:1377-1391

Joschinski J, Beer K, Helfrich-Forster C, Krauss J (2016) Pea aphids (Hemiptera: Aphididae) have diurnal rhythms when raised independently of a host plant. J Insect Sci 16:1-5

Kim JH, Jander G (2007) Myzus persicae (green peach aphid) feeding on Arabidopsis induces the formation of a deterrent indole glucosinolate. Plant J 49:1008-1019

Kjaer A (1976) Glucosinolates in the Cruciferae. In: Vaughan JG, Macleod AJ, Jones BMG (eds) The biology and chemistry of the Cruciferae. Academic Press, Cambridge, pp 207-220

Klingauf FA (1987) Feeding, adaptation and excretion. In: Minks AK, Harrewijn P (eds) Aphids, their biology, natural enemies and control, vol 2a. Elsevier, Amsterdam, pp 225-248

Kordan B, Stec K, Słomiński P, Giertych M, Wróblewska-Kurdyk A, Gabryś B (2018) Susceptibility of forage legumes to infestation by the pea aphid Acyrthosiphon pisum (Harris) (Hemiptera: Aphididae). Crop Pasture Sci 69:775-784

Kordan B, Stec K, Słomiński P, Laszczak-Dawid A, Wróblewska-Kurdyk A, Gabryś B (2019) Antixenosis potential in pulses against the pea aphid (Hemiptera: Aphididae). J Econ Entomol 112:465-474

Le Roux V, Dugravot S, Campan E, Vincent FC, Giordanengo P (2008) Wild Solanum resistance to aphids: antibiosis or antixenosis? J Econ Entomol 101:584-591

Leather SR, Awmack CS, Garratt MPD (2017) Growth and Development. In: van Emden HF, Harrington R (eds) Aphids as crop pests. CABI, Wallingford, pp 98-113

Limagrain central Europe (2018) https://www.lgseeds.pl/aktualnosci/ katalog-rzepak-ozimy-2018. Accessed 5 Mar 2019

Martin B, Collar L, Tjallingii WF, Fereres A (1997) Intracellular ingestion and salivation by aphids may cause the acquisition and inoculation of non-persistently transmitted plant viruses. J Gen Virol 78:2701-2705

Matile P (1984) Das toxische Kompartiment der Pflanzenzelle. Naturwissenschaften 71:18-24

Mayoral AM, Tjallingii WF, Castanera P (1996) Probing behaviour of Diuraphis noxia on five cereal species with different hydroxyamic acid levels. Entomol Exp Appl 78:341-348

McGregor DI (1988) Glucosinolate content of developing rapeseed (Brassica napus L. "Midas") seedlings. Can J Plant Sci 68:367-380

McLean AHC, Ferrari J, Godfray HCJ (2009) Effects of the maternal and pre-adult host plant on adult performance and preference in the pea aphid, Acyrthosiphon pisum. Ecol Entomol 34:330-338

Meier U (2018) Growth stages of mono- and dicotyledonous plants: BBCH. Monograph. Julius Kühn-Institut, Quedlinburg, Germany
Merritt SZ (1996) Within-plant variation in concentrations of amino acids, sugar, and sinigrin in phloem sap of black mustard, Brassica nigra (L.) Koch (Cruciferae). J Chem Ecol 22:1133-1145

Nault LR, Styer WE (1972) Effects of sinigrin on host selection by aphids. Entomol Exp Appl 15:423-437

Nooh S (2012) An overview of oilseed rape (canola) virus diseases in Iran. Int Res J Microbiol 3:24-28

Nosenko T, Kot T, Kichshenko V (2014) Rape seeds as a source of feed and food proteins. Pol J Food Nutr Sci 64:109-114

Paprocka M, Gliszczyńska A, Dancewicz K, Gabryś B (2018) Novel hydroxy- and epoxy-cis-jasmone and dihydrojasmone derivatives affect the foraging activity of the peach potato aphid Myzus persicae (Sulzer) (Homoptera: Aphididae). Molecules 23:1-6. https:// doi.org/10.3390/molecules23092362

Pettersson J, Tjallingii WF, Hardie J (2017) Host-plant selection and feeding. In: van Emden HF, Harrington R (eds) Aphids as crop pests. CABI, Wallingford, pp 173-195

Porejestrowe doświadczalnictwo odmianowe (2019) Charakterystyka odmian. https://www.coboru.pl/DR/charaktodmiany.aspx. Accessed 1 June 2019

Powell G (1991) Cell membrane punctures during epidermal penetrations by aphids: consequences for the transmission of two potyviruses. Ann Appl Biol 119:313-321

Prado E, Tjallingii WF (1994) Aphid activities during sieve element punctures. Entomol Exp Appl 72:157-165

Przybylski R (2011) Canola/rapeseed oil. In: Gunstone FD (ed) Vegetable oils in food technology: composition, properties and uses. Blackwell Publishing, Oxford, pp 107-136

Renwick JA, Radke CO, Sachdev-Gupta K, Stadler E (1992) Leaf surface chemicals stimulating oviposition by Pieris rapae (Lepidoptera: Pieridae) on cabbage. Chemoecology 3:33-38

Sarwar M, Sattar M (2013) Varietals variability of winter rapes (Brassica napus L.) for their susceptibility to green aphid, Myzus persicae (Sulzer) (Homoptera: Aphididae). Pak J Zool 45:883-888

Smith CM (2005) Plant resistance to arthropods Molecular and conventional approaches. Springer, Netherlands

Smith CM, Chuang WP (2014) Plant resistance to aphid feeding: behavioral, physiological, genetic and molecular cues regulate aphid host selection and feeding. Pest Manag Sci 70:528-540

Stevens M, McGrann G, Clark B (2008) Turnip yellows virus (syn Beet western yellows virus): an emerging threat to European oilseed rape production? HGCA Res Rev 69. https://cereals.ahdb.org.uk/media 1269200/rr69.pdf

ten Broeke CJM, Diecke M, van Loon J (2013) Feeding behaviour and performance of different populations of the black currant-lettuce aphid, Nasonovia ribisnigri, on resistant and susceptible lettuce. Entomol Exp Appl 148:130-171

Tjallingii WF (1995) Aphid-plant interactions: What goes on in the depth of the tissue? Proc Exp Appl Entomol 6:163-169

van Emden HF (2017) Host-plant resistance. In: van Emden HF, Harrington $\mathrm{R}$ (eds) Aphids as crop pests. CABI, Wallingford, pp 515-532

van Emden HF, Bashford MA (1969) A comparison of the reproduction of Brevicoryne brassicae and Myzus persicae in relation to soluble nitrogen concentration and leaf age (leaf position) in the Brussels sprout plant. Entomol Exp Appl 12:351-364

van Helden M, Tjallingii WF (1993) Tissue localization of lettuce resistance to the aphid Nasonovia ribisnigri using electrical penetration graphs. Entomol Exp Appl 68:269-278

Weber G, Oswald S, Zoellner U (1986) Suitability of rape cultivars with a different glucosinolate content for Brevicoryne brassicae (L.) and Myzus persicae (Sulzer) (Hemiptera, Aphididae). Z Pflanzenkr Pflanzenschutz 93:113-124

Wilkinson TL, Douglas AE (1998) Plant penetration by pea aphids (Acyrthosiphon pisum) of different plant range. Entomol Exp Appl $87: 43-50$ 
Wróblewska-Kurdyk A, Gniłka R, Dancewicz K, Grudniewska A, Wawrzeńczyk C, Gabryś B (2019) $\beta$-Thujone and its derivatives modify the probing behavior of the peach potato aphid. Molecules 24:1-16. https://doi.org/10.3390/molecules 24101847

Wyatt IJ, White P (1977) Simple estimation of intrinsic increase rates for aphids and tetranychid mites. J Appl Ecol 14:757-766

Wyniki Porejestrowych Doświadczeń Odmianowych (2015) Oleiste (rzepak ozimy). COBORU, Słupia Wielka, nr 121
Wyniki Porejestrowych Doświadczeń Odmianowych (2018) Oleiste (rzepak ozimy). COBORU, Słupia Wielka, nr 149

Publisher's Note Springer Nature remains neutral with regard to jurisdictional claims in published maps and institutional affiliations. 